\title{
Author Correction: A methylated lysine is a switch point for conformational communication in the chaperone Hsp90
}

\author{
Alexandra Rehn, Jannis Lawatscheck, Marie-Lena Jokisch (D, Sophie L. Mader (D), Qi Luo, Franziska Tippel, \\ Birgit Blank, Klaus Richter, Kathrin Lang (1), Ville R. I. Kaila (1) \& Johannes Buchner (1)
}

Correction to: Nature Communications https://doi.org/10.1038/s41467-020-15048-8, published online 5 March 2020.

In the original version of the manuscript's Supplementary Information, Supplementary Figure 2 was inadvertently duplicated and reproduced as Supplementary Figure 3. The error has now been fixed and the corrected Supplementary Information PDF is available to download.

Published online: 21 July 2020

(c) Open Access This article is licensed under a Creative Commons Attribution 4.0 International License, which permits use, sharing, adaptation, distribution and reproduction in any medium or format, as long as you give appropriate credit to the original author(s) and the source, provide a link to the Creative Commons license, and indicate if changes were made. The images or other third party material in this article are included in the article's Creative Commons license, unless indicated otherwise in a credit line to the material. If material is not included in the article's Creative Commons license and your intended use is not permitted by statutory regulation or exceeds the permitted use, you will need to obtain permission directly from the copyright holder. To view a copy of this license, visit http://creativecommons.org/licenses/by/4.0/.

(c) The Author(s) 2020 